\title{
Correction to: Enhancing attributed network embedding via enriched attribute representations
}

\section{Arzu Gorgulu Kakisim ${ }^{1}$}

Published online: 10 August 2021

(C) Springer Science+Business Media, LLC, part of Springer Nature 2021

\section{Correction to: Applied Intelligence.} https://doi.org/10.1007/s10489-021-02498-w

The original article unfortunately was published with columns/rows of Table 2 out of order.

The original article has been corrected.

Publisher's note Springer Nature remains neutral with regard to jurisdictional claims in published maps and institutional affiliations.

Dr. Arzu Gorgulu Kakisim is currently an Assistant Professor at the Department of Computer Engineering, Istanbul Ticaret University, Turkey. She received her PhD degree from the Department of Computer Engineering, Gebze Technical University, Turkey, in 2019. Her primary research interests are representation learning and community search for heterogeneous networks, and malware detection.

The online version of the original article can be found at https://doi.org/ 10.1007/s10489-021-02498-w

\footnotetext{
Arzu Gorgulu Kakisim

akakisim@ ticaret.edu.tr

1 Istanbul Commerce University, Istanbul, Kucukyali, Turkey
} 